\title{
The Analysis Performance of Midwife in the Antenatal Care and Intranatal Care Service at the Independent Practice of Midwife (BPM) in Jember District
}

\author{
Sugijati* \\ *Department Of Midwifery, Health Polytechnic Of Malang, Republic Of Indonesia
}

\begin{abstract}
Maternal Mortality Rate (MMR) the district of Jember holds the top rank across East Java province Indonesia reaching 87,73/100.000 of living birth. The major cause of the death rate especially took place in 2015 was pre-eclampsia (37,50 \%), and out of bleeding (18,75\%). Midwifery service including pregnancy check-up and delivery mostly conducted by midwives. The performance of midwife will likely impact midwifery service quality especially Antenatal Care (ANC) and Intranatal Care (INC) service. The research aimed to analyse factors which influence midwife's performance in antenatal care cervice and intranatal care at the Independent Practice of Midwife (BPM) in Jember district. The research deployed observational survey with cross sectional approach. Three independent variables were involved such as individual variable, organizational variable and psycholgical variable. Where as two dependent variables were also involved such as midwifes' performance at the antenatal care service and at the intranatan care service. Of 185 midwives in Jember district with independent practice was selected through cluster random sampling. The research instrument used questionnaire. Data was collected and analysed using statistical test of double linier regression. The research result indicated significant influence of individual, organizational and psychological factors over the performance of midwife at the antenatal care service. In addition, the influence of individual and organizational factors over the performance of intranatal care also showed up, but other wise it did not performance for psychological factor. Thus, head of health office and the chair person of professional organization such as Indonesian Midwife Association (IBI) of Jember district are suggested to provide midwives with a wide range of opportunities through seminars, symposium and periodic technical training for their better professional development.
\end{abstract}

Keywords: Performance of Midwife, Antenatal care, Intranatal care

\section{Introduction}

Indicators of people's health level and prosperity are among others the maternal mortality rate, infant mortality rate and lifespans. So far, mother's death rate becomes the top rank problem in the context of mother's and baby's health in Indonesia. Various programs have been provided through a number of sectors such as both governmental and non-governmental sector including organization.

As a matter of fact, maternal mortality rate in the district of Jember was on the top rank across East Java province reaching 142/100.000 living birth (LB) in 2010, and 142,9/100.000 LB in 2011, but in 2012 it decreased up to $116,4 / 100.000 \mathrm{LB}, 101,0 / 100.00 \mathrm{LB}$ in 2013, and in 2014 indicated another decrease of 86,13/100.000 LB, in 2015 became 87,73/100.000 LB. Yet, it indicated high numbers compared to other districts and cities in the East Java province on average (Dinkes Jember, 2005).

Factors substantially contributing to mother's death rate can be categorized into two major causes namely direct and indirect factors.The former deals with pregnancy complication, delivery and bleeding after delivery and the latter concerns factors imposing burdens to pregnancy such as too-young-pregnancy, too-oldpregnancy, too-often-pregnancy and too-short-pregnancy gapor even impeding the process of pregnancy emergency care, delivery and bleeding after delivery such aslate danger signal identification and decisionmaking, late health facility reach and late emergency care and other contributing factors such as pregnancy with infectious disease, non-infectious disease and malnutrition (Depkes, 2008). The causes of mother's death rate in the district of Jember in 2015, based on data taken from Departement of Health, pre eclampsia was in the top rank $(37,50 \%)$ while severe bleeding was in the second place (18,75\%). Almost half of mother's death caused by direct factor and the other half caused by indirect factor such as disease or another complications detected prior to delivery complication. Pregnancy health care is closely related to delivery care, bleeding after delivery and health care for a newly-born baby. The quality of antenatal care service and intranatal care will likely influence pregnancy health and the infant, delivery, newly-born baby and bleeding after delivery (Kemenkes, 2012).The performance by paramedics will also influence the quality of health care especially to that of antenatal care and delivery rescue. Gibson (2000) invented work theory model and made analysis ofa few number of variables which influence individual performance and behavior. The first variable represents 
individual variable in which skill and ability variable was the main factor in influencing individual performance and behavior while demographical variable showed indirect effect upon individual performance and practice.The second variable represents psychological variable comprising sub variables of perception, attitude, personality, learning and motivation. This variable, according to Gibson (2000), was influenced by most families, social level, working experience and demographical experience.The third was organizational variable which has indirecteffect upon individual performance and behaviour incorporated into recourse sub variable such asleadership, remuneration, structures and work design.

Indonesian Ministery of Health has devoted efforts to decrease mother's death rate by relocating centres of midwife's care nearby mothers in need. To support these efforts and to achieve target of development a large number qualified paramedics were desperately needed especially those concerned for the acceleration of mother's and bay's death rate decrease. So far, midwife's care especially antenatal care and intranatal care service mostly carried out by midwives as over 345 midwives in Jember district run independent midwife's practice (BPM). Previous research result in Jember district in 2014 to 2015 indicated that out of 10 of delivery 2 deaths took place in the independent midwife's practice while mother's death on delivery can likely be influenced by in appropriate antenatal care or conducted beyond standard operational procedure of midwifery service.

\section{Conceptual framework}

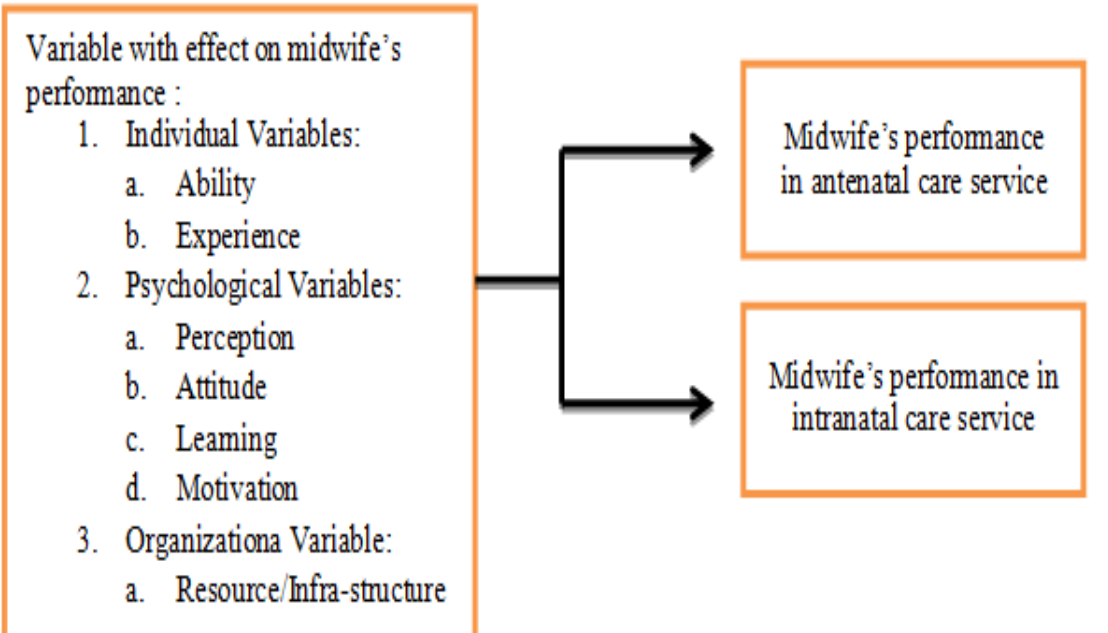

Figure (1) Conceptual Outline and Research operational

\section{General Aim}

To examine the influence of factors upon the performance of mother in the antenatal care and intranatal care service in the Independent Practice of Midwife in Jember district.

\section{Special Aim}

1. To analyse the influence of individual factor upon midwife's performance in the antenatal care service

2. To analyse the influence of organizational factor upon midwife's performance in the antenatal care service

3. To analyse the influence of psychological factor upon midwife's performance in the antenatal care service

4. To analyse the influence of individual factor upon midwife's performance in intranatal care

5. To analyse the influence of organizational factor upon midwife's performance in intranatal care

6. To analyse the influence of psychological factor upon midwife's performance in intranatal care

\section{Research Hypothesis}

Based on conceptual and operational framework, research hypothesis wasconstructed as what follows:

1. Individual variable influences midwife's performance in the antenatal care service

2. Organizational variable influences midwife's performance in antenatal care service

3. Psychological variable influencesmidwife's performance in antenatal care service

4. Individual variable influences midwife's performance in the intranatal care

5. Organizational variable influences midwife's performance in the intranatal care

6. Psychological variable influences midwife's performance in the intranatal care 


\section{Design}

\section{Research Method}

The research deployed observational survey by observing the relationship between research variables with the approach of data collection schedule with the use of cross sectional design in which data dealt with free variables and tight variables will be collected at the same time.

\section{Population and Sample}

The research population represents 345 midwives in Jember district who ran independent Midwife's Practice (BPM) normally taking care of labour. The sample calculation of the research used form introduced by Slovin: (Notoatmodjo, 2005)

\section{Notes:}

$$
n=\frac{N}{1+N\left(d^{2}\right)}
$$

$\mathrm{n}=$ total of sample

$\mathrm{N}=$ total of population

$\mathrm{d}^{2}=$ level of trust / /accuracy requested (5\%).

As population $(\mathrm{N})=345$, then the calculation result of total samples reached 185 people.

\section{Sampling Technic}

Sample collection procedure was through probability sample (Notoatmodjo, 2005) by taking representetavies from each area of Indonesian Midwife's Association (IBI) through cluster random sampling. The research deployed area unit IBI in Jember districtic which the independent midwife are in practice across 16 sub areas. Sample collection was conducted through cluster at each sub area of IBI in Jember area.

\section{Sample criteria was determined by what follows :}

1. Independent Midwife's Practice (BPM) located in 16 sub area of IBI in Jember district

2. Independent Midwife's Practice responsible for antenatal care service

3. Independent Midwife's Practice responsible for intranatal care service

The proportion of research total samplesas seen in table (1)

Table (1) The Proportion of Research total Samples

\begin{tabular}{|l|c|c|}
\hline \multicolumn{1}{|c|}{ Sub area of IBI } & Ni & Ni \\
\hline Jenggawah & 13 & 8 \\
\hline Rambipuji & 19 & 10 \\
\hline Ambulu & 24 & 13 \\
\hline Kalisat & 20 & 11 \\
\hline Sukowono & 18 & 9 \\
\hline Tempurejo & 17 & 9 \\
\hline Mayang & 15 & 8 \\
\hline Tanggul & 34 & 18 \\
\hline Jenggawah & 13 & 8 \\
\hline Rambipuji & 19 & 10 \\
\hline Ambulu & 24 & 13 \\
\hline Kalisat & 20 & 11 \\
\hline Sukowono & 18 & 9 \\
\hline Tempurejo & 17 & 9 \\
\hline Mayang & 15 & 8 \\
\hline Tanggul & 34 & 18 \\
\hline Jumlah & 345 & 185 \\
\hline
\end{tabular}

The Operasional Definition and Research Variables

1. Midwife's performance in the antenatal care service: process and the quality of work result of midwife can be observed based on duties and functions at BPM in antenatal care service. The Analysis of performance in antenatal care service consists of what follows:

1) Individual Variable; Variable which comprises ability and experience of respondent in relation to duty completion in antenatal care service.

2) Organizational Variable; Variabel dealt with the availability of resources and infra-structure such as drugs and medicines, and even transport allowance during antenatal care service.

3) Psychological Variable; Variable which consist of perception, attitude, learning and motivation such as (a) Respondent's opnion and comprehension of standard operational procedure of antenatal care service, (b) Midwife's feeling, perception and encouragement to react to antenatal care service, (c) Midwife's 
Perception and opinion upon the encouragement to learn about antenatal care, (d) midwife's level of willing and encouragement in implementing antenatal care service.

2. Midwife's performance in delivery rescue: process and the quliaty of midwife's performance result which can be observed based on duties and functions at BPM in intranatal care service.

Performance analysis in intranatal care service which comprise what follows:

1) Individula Variable; Variable which consists of ability and experience such as respondent's skills and experience in relation to duty completion in intranatal care service.

2) Organizational Variable; Variabel dealt with resources and infra-structure such as the availability of tools, drugs and medicines, and even transport allowance during intranatal care service.

3) Psychological variable; Variable comprising perception, attitude, learning and motivation such as (a) Midwife's opinion and comprehension towrads standard operational procedure of delivery rescue service,(b)Midwife's feeling, thought to react in delivery rescue service, (c)Midwife's perception /opinion towardswilling to learn delivery rescue, (d) Midwife's level of willing and encouragement in implementing intranatal care service.

\section{Data Analysis}

To test the proposed hypothesis,statistical test of double linier regression equality was taken to identify the influences of all free variables as well as tight variables through the result of ANOVA and level of significance of $5 \%(<0,05)$

III. Result

Table (2) Respondent's Characteristic (Midwife) at BPM in Jember District

\begin{tabular}{|c|l|c|c|}
\hline No. & \multicolumn{1}{|c|}{ Age } & $\mathbf{X}$ & $\mathbf{\%}$ \\
\hline 1 & $20-30$ years & 39 & 21,0 \\
\hline 2 & $31-40$ years & 57 & 30,8 \\
\hline 3 & $41-50$ years & 57 & 30,8 \\
\hline 4 & $51-60$ years & 22 & 11,9 \\
\hline 5 & $61-70$ years & 10 & 5,5 \\
\hline & Education & 2 & 1,1 \\
\hline 1 & Midwife's school & 2 & 1,1 \\
\hline 2 & Midwifery Diploma I (PPB) & 163 & 88,1 \\
\hline 3 & Midwifery Diploma III & 18 & 9,7 \\
\hline 4 & Midwifery Diploma IV & & 94 \\
\hline & Training Attended & 174 & 72 \\
\hline 1 & APN & 134 & 41 \\
\hline 2 & CTU & 76 & 56 \\
\hline 3 & PPGDON & 104 & 23 \\
\hline 4 & Asfiksia BBL Management & 42 & 55,7 \\
\hline 5 & Integrated Antenatal & & 17,3 \\
\hline & Working Experience & 93 & 20 \\
\hline 1 & $01-10$ years & 32 & 5,4 \\
\hline 3 & $11-20 y e a r s$ & 37 & 1,6 \\
\hline 5 & $21-30 y e a r s$ & 10 & \\
\hline 7 & $31-40 y e a r s$ & & \\
\hline 9 & $41-50 y e a r s$ & & \\
\hline & & & \\
\hline
\end{tabular}

Table (2) indicated that respondents' age widely ranging 31-40 and $41-50$ years $(30,8 \%$ each), where as respondents' educational background were generally Diploma III of midwifery $(88,1 \%)$. Overall, respondents have participated in some of APN training (94\%) while their working experience ranged $01-10$ years $(55,7 \%)$. 
Tabel (3) Regression Analysis of Work Variable of Antenatal Care Service

\begin{tabular}{|c|c|c|c|}
\hline Individual Variable & Beta & Sig & Adjusted R Square \\
\hline (Constant) & 14.080 & .000 & \multirow{3}{*}{$68 \%$} \\
\hline Ability & .299 & .001 & \\
\hline Experience & .081 & .082 & \\
\hline \multicolumn{4}{|l|}{ Organizational Variable } \\
\hline (Constant) & 17.083 & .000 & \multirow[t]{2}{*}{$0,5 \%$} \\
\hline Resources & .006 & .984 & \\
\hline \multicolumn{4}{|l|}{ Psychological Variable } \\
\hline (Constant) & 9.137 & .000 & \multirow{5}{*}{$45 \%$} \\
\hline Perception & -.045 & .318 & \\
\hline Attitude & .068 & .150 & \\
\hline Learning & 1.028 & .000 & \\
\hline Motivation & -.083 & .024 & \\
\hline
\end{tabular}

Table (3) indicated that all performance variables such as individual, organizational and psychological variables in the antenatal care service have significance of $<0.05$. Thus, Hipotesis nuul was rejected and this means all three variables influence midwifes' performance in the antenatal care service; the better work varibales, the better performance of antenatal care service.

Table (4) Regression Analysis of Work Variable in Intranatal Care Service

\begin{tabular}{|c|c|c|c|}
\hline Individual Variable & Beta & Sig & Adjusted R Square \\
\hline (Constant) & 13.097 & .000 & \multirow{3}{*}{$71 \%$} \\
\hline Ability & .444 & .000 & \\
\hline Experience & .037 & .543 & \\
\hline \multicolumn{4}{|l|}{ Organizational Variable } \\
\hline (Constant) & 12.912 & .001 & \multirow[b]{2}{*}{$70 \%$} \\
\hline Resources & .417 & .262 & \\
\hline \multicolumn{4}{|l|}{ Psychological Variable } \\
\hline (Constant) & 5.860 & .061 & \multirow{5}{*}{$1 \%$} \\
\hline Perception & .094 & .117 & \\
\hline Attitude & .034 & .595 & \\
\hline Learning & 1.081 & .000 & \\
\hline Motivation & -.105 & .030 & \\
\hline
\end{tabular}

Table (4) indicated that performance variable in intranatal care service which consists of individual variable and organizational variable has significance of $<0.05$. Thus, Hipotesis null was rejected which means individual variable and organizational variable influence the work in the intranatal care. This means the better the performance variable, the better the performance of intranatal care. Whereas $p$ value of psychological variable reaches $>0,05$ meaning the psychological variable does not influence the performance in the intranatal care service.

\section{Discussion}

The Influence of Individual Variable upon Performance of Antenatal Care Service

Statistical test result of variable linier regression indicated that variable of ability influences performance while variable of experience did not show the same result. At the test of ANOVA variable of ability valued $\mathrm{p}<0,05$, so that equation formula applied was readable. The equation formula which can applied to predict perceived work was $\mathrm{y}=14.080+0,299 . \mathrm{X} 1+0,081 . \mathrm{X} 2$. Whereas the equation obtained can describe work variable of antenatal careby $68 \%$, the rest depends on other variables beyond the research.

Muklas (1999) suggested that working ability was an employee's capacity in handling work loads as well as individual physical and intellectual ability. In addition, Gibson (2000) invented work theory model and made analysis upon various variables influencing individual performance and behavior. First, individual variable was put into a group of ability and skills sub variable which were the main factor in influencing individual performance and behavior. Where as demographical variable has indirect effect upon individual performance and practice. Intellectual ability is needed to show mental activities.

Based on the research result,to improve work performance especially in running independent practice at BPM, midwives need to improve their professional development through higher education and take parts in a wide range of training in relation to their jobs. As the result of double linier regression analysis, individual variable will improve the work of antenatal care 0,299 times than that of ability variable and as 0,051 times towards variable of experience. 


\section{The influence of Organizational Variable upon Performance ofAntenatal Care Service}

At regression equation work value of antenatal care indicated $17.083+0,006 . X_{1}$ which means the increase of organizational variable will likely improve the performance of antenatal care as 0,006 times ofresource variable. Another crucial contributory factor of service is infra-structure or tools such as working technical equipments, facilities supporting work performance (Sota, 2003).

Multi-purpose working tools will benefit working performance and make performance become more efficient even though such a tool is not many and hard to obtain. Based on the research result it is perceived that to improve midwife's performance at BPM the availability of tools and other infra-structures needs to be taken into consideration.

\section{The Influence of Psychological Variable upon Performance of Antenatal Care Service}

Based on test result of linier regression statistic variables of learning and motivation influenced working performance while variable of perception showed no influence upon working performance. Of ANOVA test variables of learning and motivation had value $\mathrm{p}<0,05$ it is then readable. Thus, equation formula to predict work is $\mathrm{y}=9.137+0,045 . \mathrm{X} 1+0,068 . \mathrm{X} 2+1.028 . \mathrm{X} 3+0,083 . \mathrm{X} 4$. Whereas equation obtained could only describe work variable of antenatal care as $14,5 \%$ while others are caused by variable beyond research.

Muchlas (1999) suggested that learning process is a relatively permanent change of behavior as the result of life experience. In other words, the change of behavior showed that the learning process takes place and vice versa.

Based on the research result,to improve midwife's performance at BPM learning improvement for midwife needs to be taken it no actions such as improving midwife's skills through training in relation to their tasks and duties. The improvement of psychological variable will likely improve performance of antenatal care as 0,045 times upon variable of perception, as 0,068 times upon variable of attitude, as 1.028 times upon variable of learning and as 0,083 times upon variable of motivation.

\section{The Influence of Individual Variable upon Performance of Intranatal Care Service}

Based on the test result of linier regression statistic,variable that influenced performance was variable of ability while variable of experience showed no influence to wards performance of intranatal care service. Of ANOVA test, variable of ability has value $p<0,05$ thus, the equation formula is readable. The equation formula that can be used to predict work was $\mathrm{y}=13.097+0,444 . \mathrm{X} 1+0,037 . \mathrm{X} 2$. Where as the equation obtained is able to describe variable of performance of delivery rescue as $71 \%$, the rest was identified by other variables beyond the research.

Gibson (2000) suggested that skill is ability dealt with one's task and duty implemented at the appropriate time. Appropriate skills will likely improve working performance.Based on the research result, to improve the performance of midwife at BPM improving midwife's skill and ability through higher education, training participation in relation to their tasks anad duties.

\section{The Influence of Organizational Variable Upon Performance in Intranatal Care Service}

The result of regression test indicated that Hipotesis null was rejected due to $\alpha$ counting $<0,001$. Thus, organizational variable influenced the performance in intranatal care service which means that the better the organizational variable the better the work in the delivery rescue. With regression equation $=12.912+0,417 . X_{1}$, it means that the increase of organizational variables will likely improve the performance in the intranatal care service as 0,417 times upon resource variables.

Sota (2003) suggested that the function of service infra structure are among others: 1) to accelerate the implementation of work process, so it is more efficients, 2) to improve the productivity of good and service, 3) to provide better and guaranteed quality of products, 4) to provide much easier actions, 5) to provide comfort to to those who has concerns, 6) to provide satisfaction to those who have concerns to reduce their emotional burden.

Based on the research result, to improve the performance of midwife in BPM the availibilty of tools and infra-structure is crucial especially for intranatal care service.

\section{The Influence of Psychological Variable upon the Performance in the Intranatal Care Service}

The $p$ value of Anova test $(0,061)$ is bigger than $\alpha$ standard $(0,05)$. Thus, psychological variable did not influence the performance in the intranatal care service. Where as, Porter and Miles in Danim (2004) suggested three variables which influenced individual motivations at performance. The variables mentioned are a).Worker's individual traits such as interests, attitudes, needs, and hopes, b).The workers' traits comprising tasks and duties, responsibility, and satisfaction to be likely come up, c).The environment and situation of workplace.Patterns of interaction among employees strongly influence work productivity as personal motivation 
is not an independent indicator. In the research, psychological variable consisted of perception, attitude, learning and motivation.

Two out of four variables strongly influencedthe performance in the delivery rescue namely learning and motivation varaibles, while the other two variables shoed no significant influence upon the performance. No influence shown by the two variables might be due to good motivation on averageand no high lighted variety among respondents that when connected to variable of performance in the intranatal care service which also has good value on average showed 0 correlation. This does not indicate that the value of variable is not good but it even shows good condition for both.

\section{Conclusion}

\section{Conclusion And Recommedation}

The result of double linier regression analysis indicated that variable which influenced midwife's performance of antenatal care service was individual, organizational and psychological variable. Where as, two variables influenced the work in intranatal care service that is individual and organizational variables, while psychological variable showed no influence. This does not mean that the value of the variable was not good but other wise.

\section{Recommedation}

Based on the research conclusion,the following suggestions need to be taken into consideration as they could be useful for practical purposes and for further research.

\section{To the Department of Health of Jember District}

To provide midwives with more opportunities to improve skills and ability through formal as well as nonformal education (seminar, symposium, workshop and other technical training). Holding training to refreshment and reinforcement especially dealing with materials antenatal care service and intranatal care service.

2. To Indonesian Midwife Association (IBI)

IBI should encourage members to always widen their horizon and improve skills and knowledge.

3. To researchers for further research

Further research of the same topic and theme need to be conducted with a qualitative method for more accurate result.

\section{References}

[1]. Danim, S. (2004). Motivasi kepemimpinan \& Efektivitas Kelompok. Jakarta. PT.Rineka Cipta

[2]. Depkes, RI. (2008).Panduan Pelaksanaan Strategi Making Pregnancy Safer and Child Survival, Jakarta, Depkes RI.

[3]. Dinkes Jember, (2015).Rekap Pola Persalinan dan Jumlah Kematian Maternal di Jawa Timur, Jember, Bidang Kesga.

[4]. Kemenkes RI, (2012). Pedoman Pelayanan Antenatal Terpadu, edisi kedua, Jakarta. Dirjen Bina Gizi dan KIA Direktorat Bina Kesehatan Ibu.

[5]. Muchlas, (1999).Perilaku Organisasi 1 - Organizational Behavior.Cetakan II. Yogjakarta. Program Pendidikan Pasca Sarjana UGM.

[6]. Notoatmodjo, S. (2005).Metodologi Penelitian Kesehatan, Cetakan Ketiga. Jakarta. Rineka Cipta

[7]. Sota, (2003). Pengembangan Sumber Daya Manusia,Surabaya. Airlangga University Press

[8]. Utarini, A. et.al. (1999).Jaminan Mutu Pelayanan Kesehatan; Jakarta. Direktorat Jendral Pengawasan Obat dan Makanan: 